\title{
COMBUSTION AND EMISSIONS INVESTIGATION ON LOW-SPEED TWO-STROKE MARINE DIESEL ENGINE WITH LOW SULFUR DIESEL FUEL
}

\author{
Zhiyuan Yang \\ Qinming Tan \\ Peng Geng \\ Merchant Marine College, Shanghai Maritime University, China
}

\begin{abstract}
With the implementation and expansion of international sulfur emission control areas, effectively promoted the marine low sulfur diesel fuel (MLSDF) used in marine diesel engines. In this study, a large low-speed, two-stroke, cross-head, common rail, electronic fuel injection marine diesel engine (B\&W 6S35ME-B9) was used for the study. According to diesel engine's propulsion characteristics, experiments were launched respectively at 25\%, 50\%, 75\%, 100\% load working conditions with marine low sulfur diesel fuel to analyze the fuel consumption, combustion characteristics and emissions ( $\mathrm{NOx}, \mathrm{CO}_{2}, \mathrm{CO}, \mathrm{HC}$ ) characteristics. The results showed that: Marine diesel engine usually took fuel injection after top dead center to ensure their safety control NOx emission. From 25\% to 75\% load working condition, engine's combustion timing gradually moved forward and the inflection points of pressure curve after top dead center also followed forward. While it is necessary to control pressure and reduce NOx emission by delaying fuel injection timing at 100\% load. Engine's in-cylinder pressure, temperature, and cumulative heat release were increased with load increasing. Engine's $\mathrm{CO}_{2}$ and $\mathrm{HC}$ emissions were significantly reduced from $25 \%$ to $75 \%$ load, while they were increased slightly at $100 \%$ load. Moreover, the fuel consumption rate had a similar variation and the lowest was only $178 \mathrm{~g} / \mathrm{kW} \cdot \mathrm{h}$ at $75 \%$ load of the test engine with MLSDF. HC or CO emissions at four tests' working conditions were below $1.23 \mathrm{~g} / \mathrm{kW} \cdot \mathrm{h}$ and the maximum difference was 0.2 or $0.4 \mathrm{~g} / \mathrm{kW} \cdot \mathrm{h}$ respectively, which meant that combustion efficiency of the test engine with MLSDF is good. Although the proportion of NOx in exhaust gas increased with engine's load increasing, but NOx emissions were always between 12.5 and $13.0 \mathrm{~g} / \mathrm{kW} \cdot \mathrm{h}$, which was less than $14.4 \mathrm{~g} / \mathrm{kW} \cdot \mathrm{h}$. Thus, the test engine had good emissions performance with MLSDF, which could meet current emission requirements of the International Maritime Organization.
\end{abstract}

Keywords: $\mathrm{NO}_{\mathrm{x}}$ emission; $\mathrm{CO}_{2}$ emission; marine diesel engine; combustion; marine low sulfur diesel fuel

\section{INTRODUCTION}

Shipping costs are relatively cheap, and more than $80 \%$ of the amount trade transportation of global are achieved through maritime transport[1]. Diesel engine has widely used in ship for its high thermal efficiency and performance of safe and reliability. With the continuous development of the shipping industry, the amount of exhaust gas produced by the diesel engine is gradually increasing $[2,3]$. According to statistics, there were about 600 million tons sulfur oxides (SOx), 6.5 million tons of nitrogen oxides (NOx), 1.7 million tons particulate matters into the atmosphere from the ship emissions every year $[4,5]$. Moreover, more than 70 percent of global emissions from ships are within the range of $400 \mathrm{n}$ mile from the coast, especially in high traffic ship sea ports, straits, etc., and even become the main source of emissions in the region. Exhaust emissions of marine diesel engine have seriously polluted the atmosphere and even affect human health [6,7]. All along, the diesel engine exhaust emissions influence the environment and human health of broad interest, and the study of energy saving and emission decreasing technology have aroused great attention [8].

As far as green house gas emissions are concerned, the combustion of diesel and gasoline fuels for transport purposes is the second largest source of $\mathrm{CO}_{2}$ emissions worldwide [9]. 
After the pollution of carbon emissions has been proposed at 1997, $\mathrm{CO}_{2}$ emission from ship has also been concerned. The Marine Environment Protection Committee (MEPC) of International Maritime Organization (IMO) has adopted the Energy Efficiency Design Index (EEDI) and Ship Energy Efficiency Management Plan (SEEMP) to reduce $\mathrm{CO}_{2}$ emissions from ocean transportation. And these two ship energy efficiency indicators have been included in Annex VI of the MARPOL 1973/78 to implement forcibly [10,11]. In China, the fuel consumption were more than these in the United States and China had become responsible for the most $\mathrm{CO}_{2}$ emissions of other countries. Chinese Ministry of Transport clearly stipulates: the $\mathrm{CO}_{2}$ emissions of the existing ships would be decreased by $16 \%$ to $2020[12,13]$.

There are also some other major harmful emissions from marine diesel engines including NOx and SOx. In order to reduce these emissions, International Maritime Organization (IMO) and some other related organizations (European Union) have made stringent restrictions for marine diesel engine emission. MARPOL 73/78 was adopted to prevent air pollution triggered by ships. Currently in Non Sulfur Emissions Control Area (Non-SECA) the sulfur content in diesel should be below 3.5\% while below $1 \%$ in SECA, and even in some SECA it should be less than $0.5 \%$ or $0.1 \%$, and NOx emissions should be less than $14.4 \mathrm{~g} / \mathrm{kW} \cdot \mathrm{h}$ for the diesel engine whose speed is lower than $130 \mathrm{rpm}$. According to the statistics, under the existing emissions regulations, SOx and NOx emissions will increase by more than $40 \%$ to 2020 [14]. Therefore, the ship SOx and NOx emissions requirements of the next stage is further reduced There are three Emission Control Areas (ECAs) which have been planned in china, respectively for Yangtze River Delta, Pearl River Delta and Bohai Gulf.

All the previous studies for the emissions reported were on the slow-speed two strokes marine main diesel engines fueled with relatively high sulfur content of fuel. Some researchers also noticed that the $\mathrm{CO} \backslash \mathrm{CO}_{2} \backslash \mathrm{HC} \backslash \mathrm{NOx}$ emission from those

Tab.1 Main technical specifications of test engine

\begin{tabular}{|l|l|}
\hline \multicolumn{1}{|c|}{ Model } & \multicolumn{1}{c|}{ MAN B\&W 6S35ME-B } \\
\hline Type of the engine & $\begin{array}{l}\text { 6-cylinder, in-line, water-cooled, DI } \\
\text { engine }\end{array}$ \\
\hline Number of stroke & 2 \\
\hline Compression ratio & 21 \\
\hline Bore/stroke (mm) & $350 / 1550$ \\
\hline Fire order & $1-5-3-4-2-6$ \\
\hline Rated speed (rpm) & 142 \\
\hline Rated power (kW) & 3570 \\
\hline $\begin{array}{l}\text { Scavenging port opening/ } \\
\text { closing crank angle(deg) }\end{array}$ & $142 / 218$ \\
\hline $\begin{array}{l}\text { Exhaust valve opening/ } \\
\text { closing crank angle(deg) }\end{array}$ & $115 / 278$ \\
\hline Fuel injecting angle (deg) & $2 \sim 5$ after top dead center \\
\hline $\begin{array}{l}\text { Intake type } \\
\text { Exhaust turbine or auxiliary } \\
\text { turbocharger }\end{array}$ \\
\hline
\end{tabular}

engines [15-18]. However, the marine diesel engine has been widely used Marine Low Sulfur Diesel Fuel (MLSDF) to reduce SOx emission. There is less research about the combustion and emissions characteristics of 2-stroke diesel engine with using MLSDF. So, through experiment on the MAN B\&W 6S35ME 2-stroke diesel engine of Shanghai Maritime University Automatic Engine Room, and investigate the effects of the 2 -stroke diesel engine using MLSDF on the combustion and emissions ( $\mathrm{NOx}$ and $\mathrm{CO}_{2}$ ). Mentioned effects may be useful to evaluate the emissions from the 2 -stroke diesel engines exactly in the emission control area. This paper presents the results of laboratory tests on the effects of selected MLSDF on the level of emissions.

\section{EXPERIMENTAL AND TEST METHOD}

\section{EXPERIMENTAL SETUP}

The experimental setup is shown in Fig. 1. It used MAN $\mathrm{B} \& \mathrm{~W}$ 6S35ME-B diesel engine, a large low-speed twostroke, cross-head, common rail, electronic fuel injection diesel engine, and it is widely used in the marine as the ship's propulsion power plant in most areas of world. The main technical specifications of the test engine are shown in Table 1. The diesel engine was coupled with a QC-100 hydraulic dynamometer, and the torque and speed of the diesel engine were controlled by the engine test system. In this experiment, the engine's operating conditions were controlled and their related thermal parameters were monitored by No.7 computer in Fig. 1; cylinder pressure was collected and the crank angle signal was acquired by the pressure sensor of Kistler 6613CG1; the composition of exhaust gases was analyzed by flue gas analyzer of SEMTECH ECOSTAR; diesel fuel consumption was monitor by EPC-50B-type fuel gauge for diesel engine's different operating conditions.

The fuel used in the experiment includes light diesel fuel with less than $0.5 \%$ by the weight of sulfur, which is named marine low sulfur diesel fuel. The main properties of the test fuel are shown in Table 2. All of the parameters of the test fuel conform to international standard ISO 8217-2010.

Tab.2 Properties of the testing fuels

\begin{tabular}{|c|c|c|c|c|c|}
\hline 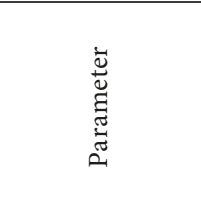 & 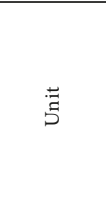 & 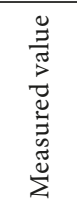 & 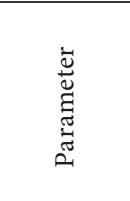 & $\overrightarrow{3}$ & 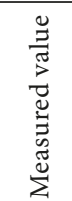 \\
\hline Cetane number & & 53 & Carbon & $\mathrm{m} \%$ & 86.07 \\
\hline Low Heat Value & $\mathrm{kJ} / \mathrm{g}$ & 42.56 & Hydrogen & $\mathrm{m} \%$ & 13.01 \\
\hline Viscosity $20^{\circ}$ & $\mathrm{mm}^{2} / \mathrm{s}$ & 4.3 & Nitrogen & $\mathrm{m} \%$ & 0.03 \\
\hline Density $20^{\circ}$ & $\mathrm{kg} / \mathrm{m}^{3}$ & 824.6 & Oxygen & $\mathrm{m} \%$ & 0.60 \\
\hline Flash point & ${ }^{\circ} \mathrm{C}$ & 82 & Sulphur & $\mathrm{m} \%$ & 0.2 \\
\hline Acid value & $\mathrm{mgKOH} / \mathrm{g}$ & 0.41 & Water & $\mathrm{V} \%$ & $<0.05$ \\
\hline
\end{tabular}




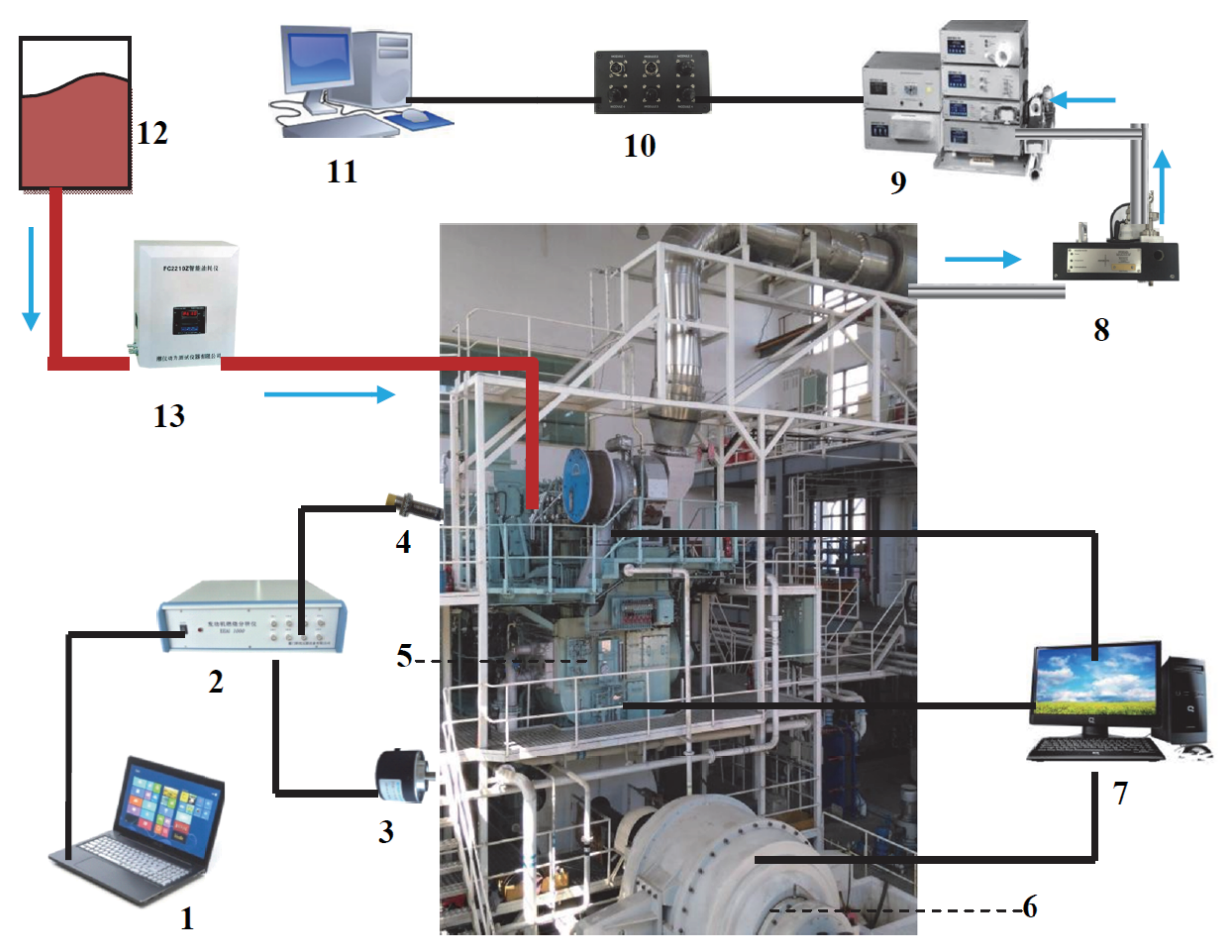

Fig. 1. Diagram of the experimental system 1.Computer for combustion analysis 2. Data acquisition 3. Crank angle sensor 4. Cylinder Pressure sensor 5. 2-stoke diesel engine 6. Hydraulic dynamometer 7. Computer for operate control and thermal parameter monitoring 8. Prefilter 9. SEMTECH ECOSTAR 10. Signal box 11. Computer for exhaust gas analysis 12. MLSDF Tank 13. Fuel consumption monitor

\section{SAMPLING AND ANALYSIS}

The pressure transducer Kistler 6613CG1, which were mounted on each cylinder head, measured the cylinder gas pressure of the engine. The pressure sensor was used with a charge amplifier and a shaft encoder to obtain the cylinder pressure data at 0.5 crank angle intervals. The pressure data were averaged 100 consecu-tive cycles for the experiment in all engine conditions. The averages of the pressure data were analyzed with a combustion analyzer to analysis the heat release rate, which was computed from the averaged cylinder pressure data using Equation (1) [18]:

$$
\frac{\mathrm{dQ}_{\mathrm{g}}}{\mathrm{d} \varphi}=\frac{\mathrm{dQ}_{\mathrm{n}}}{\mathrm{d} \varphi}+\frac{\mathrm{dQ}_{\mathrm{W}}}{\mathrm{d} \varphi}
$$

Whereis the net heat release rate, and it was obtained by the traditional first law using Eq. (2) [19]:

$$
\frac{d Q_{n}}{d \varphi}=\frac{\gamma}{\gamma-1} \cdot p \cdot \frac{d V}{d \varphi}+\frac{1}{\gamma-1} \cdot V \cdot \frac{d p}{d \varphi}
$$

And is the heat loss rate, and it was determined from Equation (3) in which the hc was estimated by the Woschni model.

$$
\frac{\mathrm{dQ}_{\mathrm{w}}}{\mathrm{d} \varphi}=\mathrm{A}_{\mathrm{ht}} \mathrm{h}_{\mathrm{c}}(\mathrm{T}-\mathrm{Tw}) / 6 \mathrm{n}
$$

The gaseous emissions from the marine auxiliary diesel engine were measured with a mobile test system (SEMTECHECOSTAR, Sensor, Inc.) for $\mathrm{NOx} \mathrm{O}_{2} \backslash \mathrm{HC} \backslash \mathrm{CO} \backslash \mathrm{CO}_{2}$ gas emissions. The principle of SEMTECH-ECOSTAR for NOx is based on Beer-Lambert law, including analyzing $\mathrm{CO} / \mathrm{CO}_{2}$ by Non-dispersive Infrared (NDIR) to, testing NOx by Nondispersive Ultraviolet (NDUV), testing THC by Heated Flame Ionization Detector (HFID) and with paramagnetic oxygen test unit.

\section{TEST METHOD}

In this research, the tests were carried out at steady states to evaluate the effects of the MLSDF on the combustion, $\mathrm{NOx}, \mathrm{O}_{2}, \mathrm{HC}, \mathrm{CO}$ and $\mathrm{CO}_{2}$ gas emissions with different loads at the speed of $25 \% \sim 100 \%$ rated speed for the propulsion characteristic test mode (Table 3 ). In all testing condition, the diesel engine was allowed to run for one hour after the cooling water temperature, exhaust gas temperature and lubricating oil temperature have reached steady-state values. The cooling water temperature was kept between $70^{\circ} \mathrm{C}$ and $80^{\circ} \mathrm{C}$, and the piston cooling oil temperature was about $50^{\circ} \mathrm{C}$, depending on the engine speeds and loads. Within 1 hour after each stable operation condition, every ten minutes to collect these data which including the cylinder pressure and composition of exhaust gas, automatic record the fuel consumption rate every 1 second duration. Each type parameter would be average to evaluate the diesel engine's combustion, emission, and economic performance.

Tab.3 Engine operating conditions

\begin{tabular}{|l|c|c|c|c|}
\hline Load $(\%)$ & 25 & 50 & 75 & 100 \\
\hline Power $(\mathrm{kW})$ & 892 & 1795 & 2677 & 3575 \\
\hline Speed $(\mathrm{r} / \mathrm{min})$ & 89.5 & 112.8 & 129 & 142 \\
\hline Fuel consumption $(\mathrm{kg} / \mathrm{h})$ & 197 & 342 & 478 & 644 \\
\hline
\end{tabular}




\section{RESULTS AND DISCUSSION}

\section{ECONOMIC PERFORMANCE}

Compared with ordinary marine diesel fuel, the marine low sulfur diesel fuel has low flash point, low viscosity, low specific gravity, low lubricity, low calorific value and so on, which not only bring much difficulties for the ship fuel management, but also have an impact on diesel engines' combustion and emission performance. For example, low viscosity leads to the increase of fuel high pressure pump leakage and the decrease of fuel injection pressure, which may be lower than the valve opening pressure of the fuel and even stop the engine. The economic, combustion and emissions performances of MAN B\&W 6S35ME-B9 with MLSDF will be analyzed below.

As can be seen from Table.3, according to the thrust characteristics, the fuel consumption per hour is gradually increased with the load increasing. However, the fuel consumption per unit of power per hour decreased after it first increased with the load increasing. The lowest fuel consumption rate is only $178 \mathrm{~g} / \mathrm{kW} \cdot \mathrm{h}$ at $75 \%$ load. It is difficult for diesel engine to run at rated condition for the variability of load from the external environment of ship. Usually relatively low speed conditions are accepted to increase efficiency of ship propulsion. Therefore, the diesel engine fuel consumption rate is relatively low under about $75 \%$ load working conditions. Overall, during the high-load range of diesel engine, its cylinder temperature is high at injection timing and high pressure of fuel injection, which is more favorable for combustion. And if combustion efficiency is improved, its fuel consumption rate is lower than under low load conditions.

\section{COMBUSTION CHARACTERISTICS}

The in-cylinder pressure, heat release rate, cumulative heat release and temperature curves for different load are shown in Fig. 3 to Fig. 6. Pressure curve shown in Fig. 2 from the average of collected six pressure data of No.1 cylinder in one hour, and each pressure acquired was averaged over 1000 cycles to diminish the influence of cycle-by-cycle variation. The heat release rate, cumulative heat release and temperature were analyzed from the in-cylinder pressure data.

After the exhaust gas turbocharger boosting and the air cooler cooling, the fresh air is taken as the intake gas of twostroke diesel engine. The in-cylinder temperature rests on temperature and pressure of intake gas, which would affect the process of fuel combustion. As shown in Fig. 3, despite the scavenge temperature changed little, when the load gradually increased from $25 \%$ to $100 \%$, the scavenging pressure was significantly increased. So, the compression pressures and temperatures have increased, which is in favor of in-cylinder fuel combustion. We can see from Fig. 4 to Fig. 7 that the variation rules of cylinder thermal parameter curves are similar under the engine's different operator conditions. When engine's load was increased from $25 \%$ to $100 \%$, the compress pressure at top dead center and the peak combustion pressure were obviously increased, and the whole pressure curve moved upward. Though the rule of heat release rate changed little, the cumulative heat release significantly increased and cylinder temperature curve moved upward. More importantly, the peak pressure and temperature are relatively high when the two-stroke marine diesel engines work at rated operating condition. Thereby, fuel injection after top dead center is accepted to reduce the peak cylinder pressure and maximum temperature, which can ensure their safety of cylinder and reduce the NOx formation.

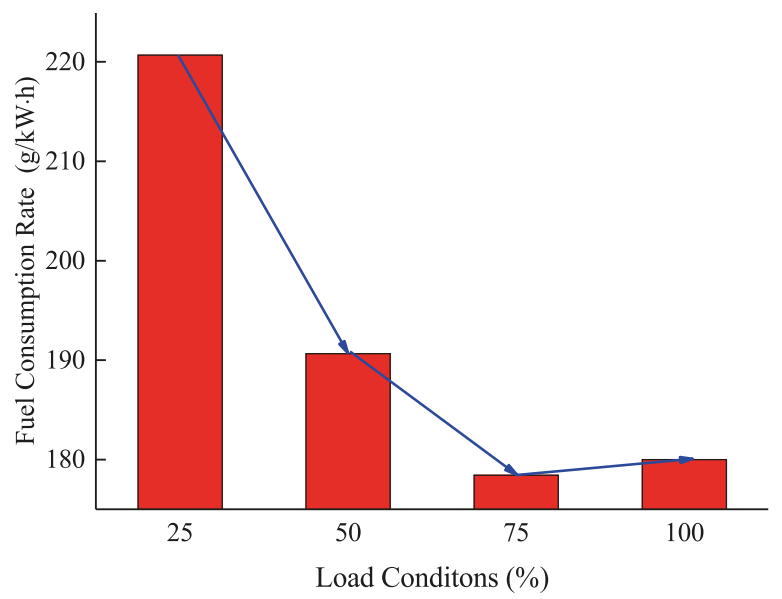

Fig. 2. Fuel consumption rate

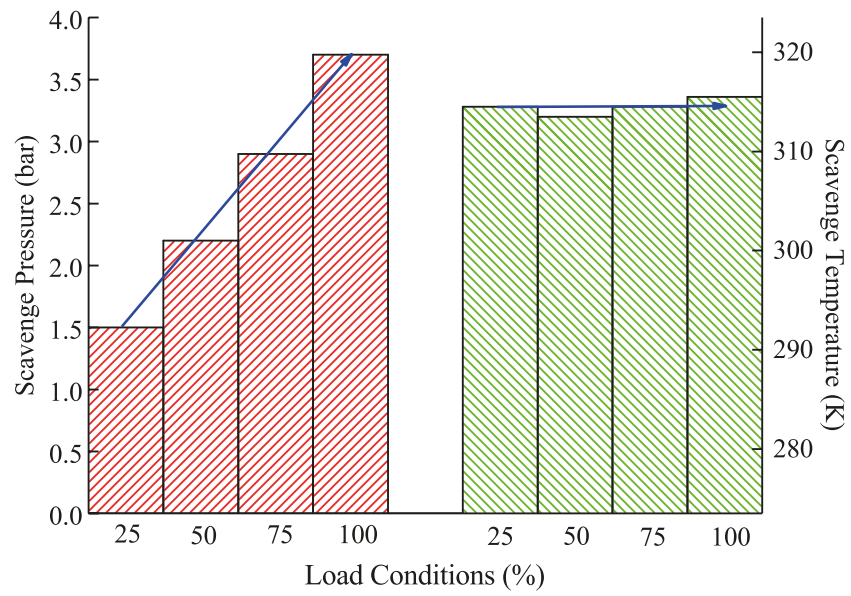

Fig. 3. Thermodynamic parameters of scavenge

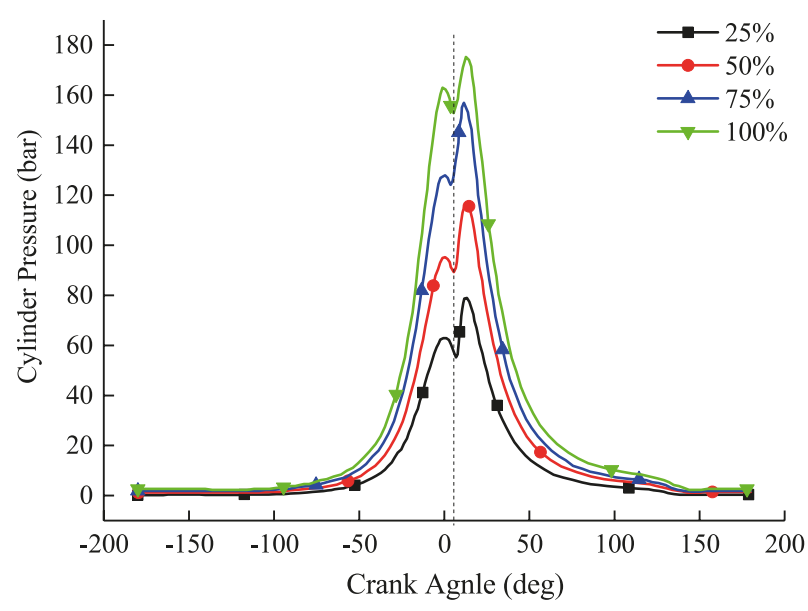

Fig. 4. In-cylinder pressure 
In this experiment, the concentration and motion of the mixture in the cylinder remain about the same for the test fuels, and thus the combustion duration of the test fuels are influenced by the fuel injection timing, injection quantity and the temperature of the diffusive mixture. And the injection timing is same at the operating condition respectively with $25 \%, 50 \%$ or $75 \%$ load. As shown in Fig. 5 and Fig. 6 , the combustion timing gradually moves forward with the load increasing, and this is because the injection pressure and temperature increase at the injection timing, which is effective to promote fuel evaporation and mixture of fuel and air, fuel injection quantity increases at high-load effectively, which improves fuel fog.
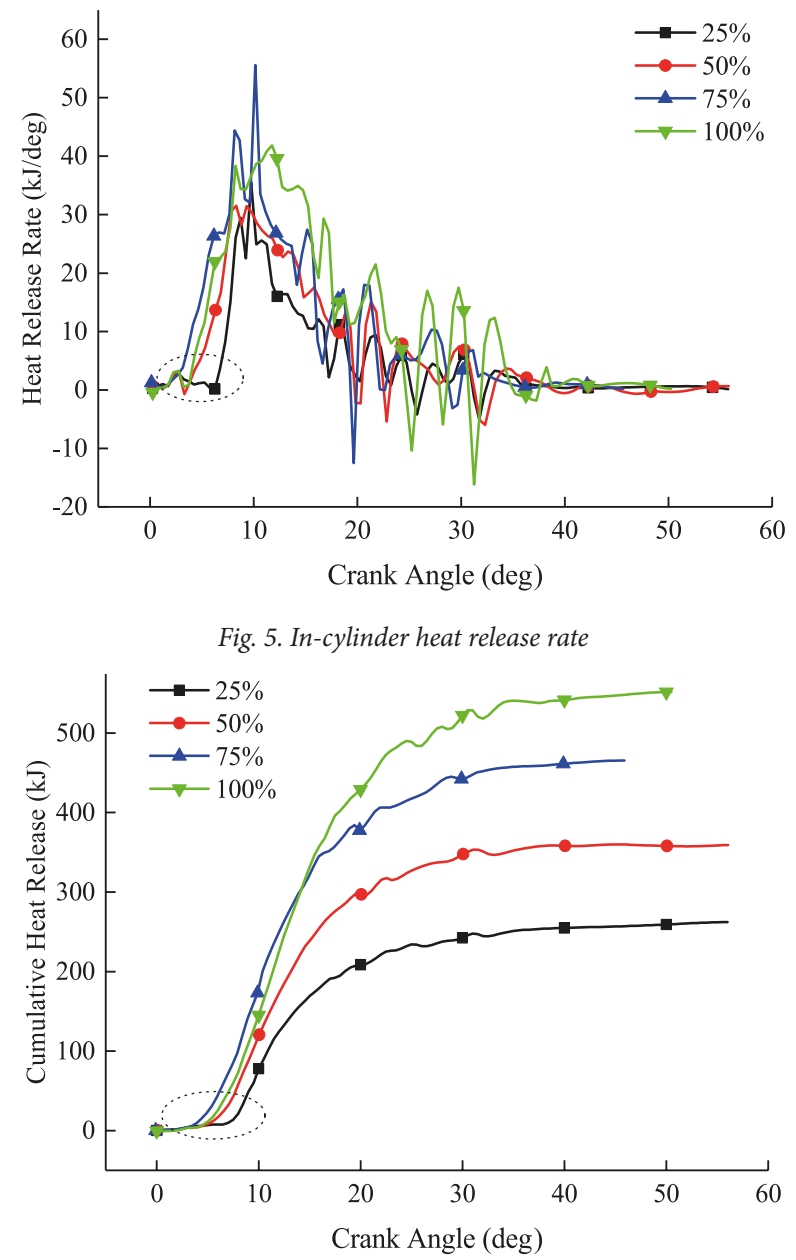

Fig. 6. In-cylinder cumulative heat release

That is why heat release rate and cumulative heat release increase by combustion improved at the same crank angle position. Thus, the inflection points of pressure curve after top dead center also follow forward (shown in dashed lines in Fig.4. However, the inflection point of the pressure and heat release rate at $100 \%$ load are later than at $75 \%$ load condition, which is caused by injection timing delayed. That because the cylinder pressure and temperature are really high at $100 \%$ load working condition. So, injection timing needs to be delayed to control their maximum combustion pressure and cylinder temperature. Curve shows that the heat release rate, cumulative heat release, temperature and pressure rises were relatively low at the pre-combustion of $100 \%$ load. However, all that in-cylinder thermal parameters at aft-combustion of $100 \%$ load were more than $75 \%$ load condition.

From what is mentioned above, we can keep the engines' NOx emissions not exceeded and advance the injection timing to improve combustion efficiency and reduce carbide emission at low-load condition. It is necessary to delay injection timing to control NOx emission at high load conditions. Thus we can adjust injection timing at different conditions according to the ship engines' emission required.

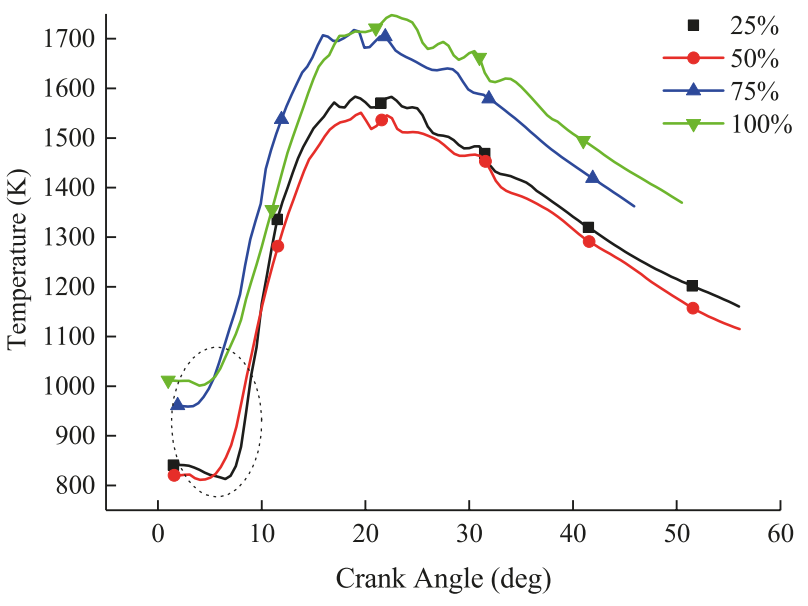

Fig. 7. In-cylinder temperature

\section{THERMODYNAMIC PARAMETERS OF EXHAUST GAS}

Thermodynamic parameters of exhaust gas at different engine speeds and engine loads for the diesel engine are discussed in this section Fig. 8 shows the pressure and temperature of exhaust manifold when the diesel engine operates on different speeds and loads. Exhaust pressure directly affects the performance of exhaust gas turbocharger and determines the pressure of the diesel engines' scavenge air, then affects the combustion and emissions performance of diesel engine. The exhaust gas pressure is relatively low at low load (the absolute pressure is only 1.4 bar at $25 \%$ load), which leads to poor effect of supercharge, low scavenging air pressure, bad ventilation effect and deterioration of combustion. So usually use an auxiliary blower to increase the scavenging pressure at low loads of marine diesel engines. As shown in Fig. 8, the temperature of exhaust manifold increases significantly with the increase of engine speeds and loads. When the diesel engine operates at the low engine speed and loads, the temperature of the exhaust manifold is less than $200^{\circ} \mathrm{C}$, while the temperature can reach more than $370^{\circ} \mathrm{C}$ when the test engine operates at the high speed and load. The temperature of exhaust manifold has the significant influence on the emissions from the diesel engine, including $\mathrm{NOx}, \mathrm{CO}$ and so on. Moreover, there are also some chemical reactions between $\mathrm{NO}$ and $\mathrm{NO}_{2}$, due to the changes of the rate of conversion. The factors, which lead to the influence of the emissions, still need further research. 


\section{EMISSIONS}

As shown in Fig. 9, the exhaust gas was consisted of about $80 \% \mathrm{~N}_{2}, 16 \% \mathrm{O}_{2}, 4 \% \mathrm{CO}_{2}$ and minimal polluting gas. The polluting gas consists mainly of $\mathrm{NOx}, \mathrm{CO}, \mathrm{CO}_{2}$ and $\mathrm{HC}$, which accounted for only $0.1 \%$ of the total amount of exhaust gas. In the following, its various polluting gas emissions will be explored at different operating condition with the use of marine low sulfur diesel fuel.

\section{1) NOx emission}

The total NOx emissions from the engine exhaust at different engine speeds and loads are shown in Fig .9 and Fig. 10.

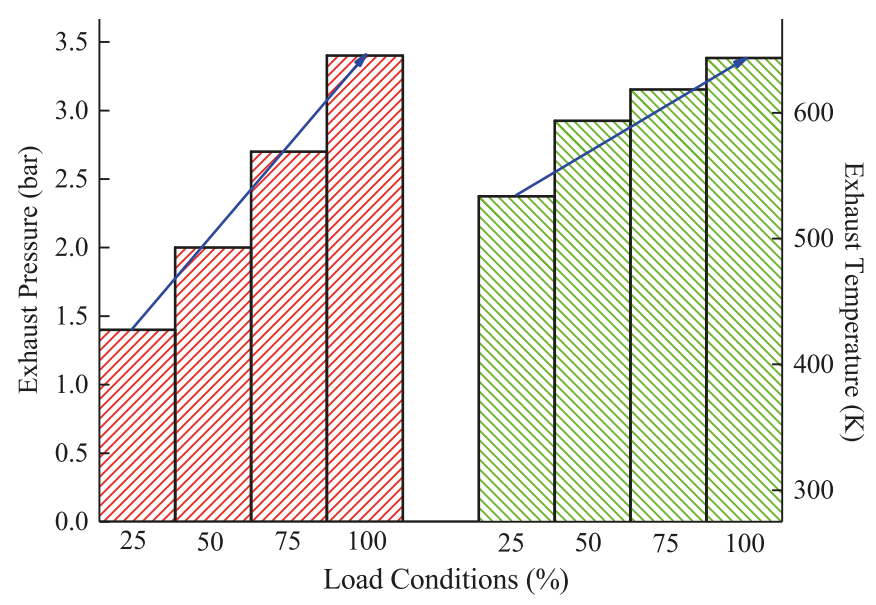

Fig. 8. Thermodynamic parameters of exhaust gas

When the diesel engine operates on the $25 \%$ load, the total NOx emissions is about $740 \mathrm{ppm}$, while increase significantly with the load increases from $50 \%$ to $100 \%$. When the test engine operates on the high engine condition, the total NOx emissions can reach $880 \mathrm{ppm}$. The high temperature is the major factor leading to the increase of the total $\mathrm{NOx}$ emissions. The in-cylinder temperature increases significantly with the increase of the engine speeds and loads. However, the high temperature is not the only factors for NOx generation, but also with the oxygen concentration within environment and the time of during high temperature. Therefore, the NOx formation in-cylinder of diesel engine is a complex chemical reaction process [20,21]. As can be seen from Fig. 9, the NOx emissions at $25 \%$ load condition are more than $50 \%$ load condition. The main reason why the total amount of NOx increased is that the time of staying the high temperature zone is longer when the engine operates at $25 \%$ load with a relatively low speed. These are just the proportion of NOx in exhaust gas. However, the requirements of IMO for ship emissions are measured with the total emissions mass for each power out within one hour. As shown in Fig. 10, there is no rule to follow for NOx emissions with the load change. NOx emission is relatively low at $100 \%$ load condition for the test engine's four experimental conditions, and the NOx emission at $25 \%$ and $75 \%$ load were less than $50 \%$ working condition. NOx emissions were up to $12.96 \mathrm{~g} / \mathrm{kW} \cdot \mathrm{h}$ at $75 \%$ load work condition. All mentioned above further indicates

that the process of NOx formation is complex, which depends on the extent of the above three factors influence. Overall, the NOx emissions are always between 12.5 and 13.0 $\mathrm{g} / \mathrm{kW} \cdot \mathrm{h}$, which is less than $14.4 \mathrm{~g} / \mathrm{kW} \cdot \mathrm{h}$ and meet the ships' emission requirements of IMO.

\section{2) $\mathrm{CO}_{2} / \mathrm{CO} / \mathrm{HC}$ emissions}

It is well known that $\mathrm{CO}_{2}$ emissions are the green house gas emissions, which will lead to the global warming. $\mathrm{CO}_{2}$ is the primary green house gas and it is of high concern both for environmental reasons and fuel economy [22]. It is more important for the marine diesel engine because of its high fuel consumption and broad navigation area.

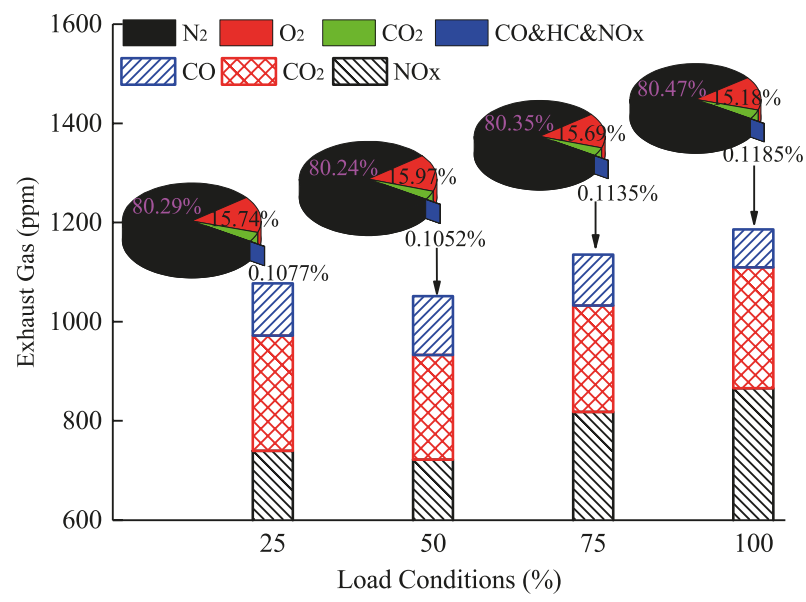

Fig. 9. Composition of exhaust gas

Thus, most of governments plan to decrease the $\mathrm{CO}_{2} / \mathrm{CO} /$ $\mathrm{HC}$ emissions in their reports on the work of the government. Fig. 10 shows the influence of the engine speed and load on the $\mathrm{CO}_{2} / \mathrm{CO} / \mathrm{HC}$ emissions. The variation rule of $\mathrm{CO}_{2} / \mathrm{HC}$ emissions with the load changed is similar to parabola, while the rule of $\mathrm{CO}$ emissions is similar to inverse parabola.

$\mathrm{CO}_{2}$ emissions of the 2-stroke diesel engine were close to $700 \mathrm{~g} / \mathrm{kW} \cdot \mathrm{h}$ at the $25 \%$ load, while it is only $560 \mathrm{~g} / \mathrm{kW} \cdot \mathrm{h}$ at high engine speed and load. $\mathrm{CO}_{2}$ emissions are significantly reduced from $25 \%$ load to $75 \%$ load, but increased slightly at $100 \%$ load condition. The maximum difference of $\mathrm{CO}_{2}$ emissions were $132 \mathrm{~g} / \mathrm{kW} \cdot \mathrm{h}$. As we all known, $\mathrm{CO}_{2}$ is the production of $\mathrm{C}$ atoms' complete combustion from fuel and energy released is a certain for per unit of $\mathrm{CO} 2$ generated. The greater $\mathrm{CO}_{2}$ emissions per unit power output means that energy consumption is greater per unit power output. It is suggested that the diesel engine has different thermal conversion efficiency for different operating conditions. Thermal conversion efficiency depends on the gas species and thermal parameters (temperature, pressure et.al) of combustion environment in-cylinder $[23,24]$. At low speed and low load work condition of diesel engine, heat transfer losses large for its low temperature of cylinder wall and piston, and its initial cylinder gas temperature and pressure are relatively low, moreover, its scavenge temperature and 
pressure are relatively low. So, the thermal conversion efficiency is low and heat consumption per power output is bigger. However, $\mathrm{CO}_{2}$ emissions per unit power output increase to some certain at $100 \%$ load working condition, which may be due to the proportion of $\mathrm{CO}_{2}$ increased in exhaust gas cylinder. Just because three-atom gases $\mathrm{CO}_{2}$ have a bigger specific heat capacity the performance of power output would be affected. The heat energy for power output is directly from the fuel combustion, and therefore directly determines the fuel consumption rate. Fig. 2 and Fig. 10 show that the low of fuel consumption rate variation is similar to its $\mathrm{CO}_{2}$ emission.

In addition, fuel consumption rate is also closely associated with the combustion efficiency. The fuel would directly generate $\mathrm{CO}_{2}$ and $\mathrm{H} 2 \mathrm{O}$ after complete combustion, otherwise $\mathrm{CO}$ and $\mathrm{HC}$ will be generated.

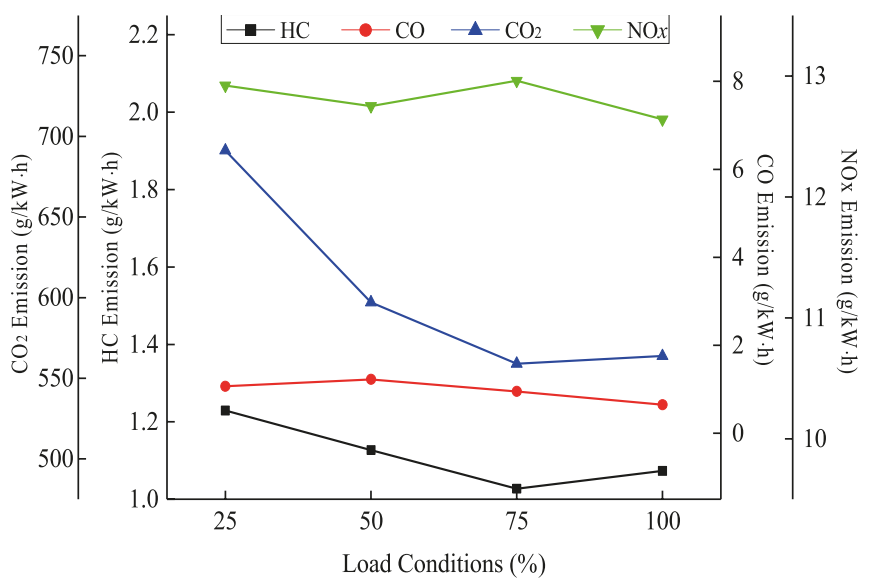

Fig. 10. Polluting gas in exhaust gas

As can be seen from Fig. 10, diesel engine's HC emission changing with conditions variation is similar with $\mathrm{CO}_{2}$, while CO emission is first increased and then decreased. Diesel engine combustion process is very complex, and the main factors are the amount of air, thermal parameters of air, fuel injection pressure, fuel-air ratio, degree of evenly mixed oil mist and so on $[25,26]$. At low load operate conditions, the low pressure of fuel injection pressure is not conducive to fuel evaporation and mist air mixing, and its relatively low initial temperature is not conducive to flame spread, which affects the combustion efficiency to a certain extent, and $\mathrm{HC}$ and $\mathrm{CO}$ emissions increase. Based on the reverse principle, $\mathrm{CO}$ and $\mathrm{HC}$ emissions are relatively low at high load. Interestingly, $\mathrm{HC}$ emissions at $100 \%$ load condition are greater than $75 \%$ load conditions. Mainly because engine's speed is faster and combustion time is shorter, more $\mathrm{HC}$ is generated accompanied by the incomplete combustion. As can be also seen from Fig. 10, HC and CO emissions changed little at the four test operating conditions of diesel engine. The maximum difference is 0.2 or $0.4 \mathrm{~g} / \mathrm{kW} \cdot \mathrm{h}$ respectively. Thereby indicating that the fuel burn fully through all over the load of the test 2-stroke marine diesel engine.

\section{CONCLUSIONS}

Experiments were conducted on an MAN B\&W 6S35ME-B diesel engine, which is a large low-speed two-stroke, crosshead, common rail, electronic fuel injection diesel engine. Based on marine low sulfur diesel fuel, the influence were evaluated on the fuel consumption, combustion characteristic (in-cylinder pressure, temperature and heat release rate), and $\mathrm{NOx} / \mathrm{CO} / \mathrm{HC} / \mathrm{CO}_{2}$ emissions. The test diesel engine is widely used as the ship propulsion device in the marine. Based on the experimental data, the main conclusions are shown as follows:

1) The combustion starts after top dead center and ignition advances with the increase of engine loads from $25 \%$ to $75 \%$ load, more over the inflection points of pressure curve after top dead center also following forward. Engine's in-cylinder pressure, temperature, and cumulative heat release were increased as load increasing. While it is necessary to delay the injection timing at $100 \%$ load to control the maximum combustion pressure and $\mathrm{NOx}$ emissions.

2) With the use of MLSDF, fuel consumption rate of high load conditions is relatively lower than the low load. Fuel consumption rate of about $75 \%$ load conditions is relatively low. It is only $178 \mathrm{~g} / \mathrm{kW} \cdot \mathrm{h}$ at $75 \%$ load of the test engine.

3) The NOx percentage of the exhaust gas increases with the engine load. There are more than three factors affecting NOx generation and its chemical reaction process is complex. The NOx emissions of the test engine with MLSDF are always between 12.5 and $13.0 \mathrm{~g} / \mathrm{kW} \cdot \mathrm{h}$, which is less than $14.4 \mathrm{~g} / \mathrm{kW} \cdot \mathrm{h}$ and meets the ships' emission requirements of IMO.

4) $\mathrm{CO}_{2}$ emissions are significantly reduced from $25 \%$ to $75 \%$ load, but increased slightly at $100 \%$ load condition. The maximum difference of $\mathrm{CO}_{2}$ emissions were $132 \mathrm{~g} / \mathrm{kW} \cdot \mathrm{h}$. The greater $\mathrm{CO}_{2}$ emissions per unit power output means that thermal conversion efficiency is lower and its fuel consumption rate would be greater.

5) The $\mathrm{HC}$ or $\mathrm{CO}$ emissions are low and its maximum difference is 0.2 or $0.4 \mathrm{~g} / \mathrm{kW} \cdot \mathrm{h}$ respectively. It indicates that the fuel burn fully through all load of the test engine with MLSDF. HC or CO emissions decide combustion efficiency and affect fuel consumption rate.

\section{ACKNOWLEDGEMENTS}

The authors would like to acknowledge the financial supports to the research provided by the National Natural Science Foundation of China (51709163), Science and Technology Commission Shanghai Municipalit (18DZ1202902).

\section{REFERENCES}

1. Eyring V., Isaksen I.S.A., Berntsen T., Collins W.J., Corbett J.J., Endresen O., Grainger R.G., Moldanova J., Schlager H., Stevenson D.S.. Transport impacts on atmosphere and climate: shipping. Atmospheric Environment. 44(37), 47354771, 2010. 
2. Jostein K. Sundet, Stig B. Dalsøren, Ivar S. A. Isaksen, Tore F. Berglen. Emission from international sea transportation and environmental impact. Journal of Geophysical Research Atmospheres. 108 (D17), 4560, 2003.

3. Eyring, V., Köhler, H.W., van Aardenne, J., Lauer, A.. Emissions from international shipping: 1. The last 50 years. Journal of Geophysical Research Atmospheres. 110 (D17), 1-12, 2005.

4. Bajic J., Simunovic, S., Steiner S.. Air Transport in the European System of $\mathrm{CO}_{2}$ Emissions Trading. Hrvatsko Znanstveno Drustvo za Promet. 33(1-2), 123-129, 2013

5. Corbett, J.J., Fischbeck, P.S., Pandis, S.N.. Global nitrogen and sulfur inventories for oceangoing ships. Journal of Geophysical Research Atmospheres. 104(3), 3457-3470, 1999.

6. Koenig D. Global and regional approaches to ship air emissions regulation: the international maritime organization and the European Union. Advances in Space Research the Official Journal of committee on Space Research. 31(1), 25, 2013.

7. Eyring, V., Isaksen, I.S.A., Berntsen, T., Collins, W.J., Corbett, J.J., Endresen, O., Grainger, R.G., Moldanova, J., Schlager, H., Stevenson, D.S. Assessment of Transport impacts on climate and Ozone: shipping. Berichte Der Bunsengesellschaft Für Physikalische Chemie. 98 (9): 11091110, 2009.

8. Bond, T.C., Doherty, S.J., Fahey, D.W., Fprster P.M., Berntsen T., DeAngelo B.J., Flanner M.G., Ghan S., Karcher B., Koch D.. Bounding the role of black carbon in the climate system: a scientific assessment. Journal of Geophysical Research Atmospheres. 118(11), 5380-5552, 2013.

9. Andy H.F., Anthony J.M., Kirk R.S., Lan R., James W.M., Anil M., Ben G.A., Diarmid C.L., Alan D.D., Michael D., Nigel B., Cathryn T.S., Mark B., Paul W.. Public health benefits of strategies to reduce greenhouse-gas emission: overview and implications for policy makers. The Lancet. 374(9707), 2104-2114, 2010.

10. Psaraftis H.N.. Market-based measures for greenhouse gas emissions from ships: a review. Wmu Journal of Maritime Affairs. 11(2), 11:211-232, 2012.

11. Schinas O., Stefanakos C.N.. Selecting technologies towards compliance with MARPOL Annex VI: The perspective of operators. Transportation Research Part D-Transport and Environment. 28(28), 28-40, 2014.

12. Hongxia W., Hong F., Xueying Y., Ke W.. Development of natural gas vehicles in China: an assessment of enabling factors and barriers. Energy Policy. 85, 80-93, 2015.
13. Lamas M.I., Rodriguez C.G., Aas H.P.. Computational fluid dynamics analysis of NOx and other pollutants in the man $\mathrm{B} \& \mathrm{~W} 7 \mathrm{~S} 50 \mathrm{MC}$ marine engine and effect of EGR and water addition. International Journal of Maritime Engineering. 155, 81-88, 2013.

14. Yang Z.L., Zhang D., Caglayan O., Jenkinson I.D., Bonsall S., Wang J., Huang M., Yan X.P.. Selection of techniques for reducing shipping NOx and $\mathrm{SOx}$ emissions. Transportation Research Part D-Transport and Environment. 17, 478-486, 2012.

15. Francersco D.N.., Claudia C.. Particulate matter in marine diesel engines exhausts: Emissions and control strategies. Transportation Research Part D-Transport and Environment. 40, 166-191, 2015.

16. Kowalski J. An experimental study of emission and combustion characteristics of marine diesel engine with fuel pump malfunctions. Applied Thermal Engineering. 65, 469- 476, 2014.

17. Gokalp B., Buyukkaya E., Soyhan H.S. Performance and emissions of a diesel tractor engine fueled with marine diesel and soybean methyl ester. Biomass and Bioenergy. 35, 3575-3583, 2011.

18. Rakopoulos D.C.. Heat release analysis of combustion in heavy-duty turbocharged diesel engine operating on blends of diesel fuel with cottonseed or sunflower oils and their bio-diesel. Fuel. 96(1), 524-534, 2012.

19. Khabbaz S.A., Mobasheri R.. Experimental investigation of the effects of Tri-aromatic utilization on combustion process, emission characteristics and engine performance of a DI diesel engine. Fuel. 123, 26-32, 2014.

20. Chaparala S.V., Raj A., Chung S.H.. Reaction mechanism for the formation of nitrogen oxides during coke oxidation in fluidized catalytic cracking units. Combustion Science and Technology. 187(11), 1683-1704, 2015.

21. Rangel L.P., Buchler P.M.. Study of nitrogen in the combustion of natural gas. Quimica Nova. 28(6), 957-963, 2005.

22. Sharpe B., Muncrief R.. Literature review: real-world fuel consumption of heavy-duty vehicles in the United States, China, and the European Union. Annales De Dermatologie Et De Vénéréologie. 140(12), S553, 2013.

23. Yoon S.J., Collins J., Thiruvengadam A., Gautam M., Herner J., Ayala A.. Criteria pollutant and greenhouse gas emissions from CNG transit buses equipped with three-way catalysts compared to lean-burn engines and oxidation catalyst technologies. Journal of Air and Waste Management Association. 63(8), 923-933, 2013. 
24. Karavalakis G., Hajbabaei M., Durbin T.D., Johnson K.C., Zheng Z.Q., Miller W.J.. The effect of natural gas composition on the regulated emissions, gaseous toxic pollutants, and ultrafine particle number emissions from a refuse hauler vehicle. Energy. 50(1), 280-291, 2013.

25. Fontaras G., Martini G., Manfredi U., Marotta A., Krasenbrink A., Maffioletti F., Terenghi R., Colombo M.. Assessment of on-road emissions of four Euro V diesel and CNG waste collection 2 trucks for supporting air-quality improvement initiatives in the city of Milan. Science of the

\section{CONTACT WITH THE AUTHORS}

\author{
Qinming Tan \\ e-mail:qmtan@shmtu.edu.cn
}

Merchant Marine College Shanghai Maritime University Shanghai 201306

CHINA

26. Hajbabaei M., Karavalakis G., Johnson K.C., Lee L., Durbin T.D.. Impact of natural gas fuel composition on criteria, toxic, and particle emissions from transit buses equipped with lean burn and stoichiometric engines. Energy. 62(6), 425-434, 2013. 